\title{
Performance of calves born in different periods of the calving season in intensive beef cattle farming
}

\author{
[Desempenho em pecuária de corte intensiva de progênies nascidas em diferentes \\ períodos da estação de parição]
}

\author{
R.Z. Vaz ${ }^{1}$, J.F.P. Lobato' ${ }^{2}$ J. Restle ${ }^{3}$, V.G.D. Conceição $o^{4}$, \\ O.G.L. Ferreira ${ }^{5}$, J.L.B. Costa ${ }^{6}$, L.R. Eloy ${ }^{6}$
}

\author{
${ }^{1}$ Departamento de Zootecnia, Universidade Federal de Santa Maria - Campus Palmeira das Missões, RS \\ ${ }^{2}$ Faculdade de Agronomia, Universidade Federal do Rio Grande do Sul - Porto Alegre, RS \\ ${ }^{3}$ Faculdade de Veterinária e Zootecnia, Universidade Federal de Goiás - Goiânia, GO \\ ${ }^{4}$ Aluno de Pós-Graduação - Universidade Federal de Santa Maria - Campus Palmeira das Missões, RS \\ ${ }^{5}$ Departamento de Zootecnia, Faculdade de Agronomia, Universidade Federal de Pelotas - Capão do Leão, RS \\ ${ }^{6}$ Aluno de Pós-Graduação - Universidade Federal do Rio Grande do Sul - Porto Alegre, RS
}

\begin{abstract}
The objective of this study was to evaluate, for two years, the performance of 124 female and 105 male Braford calves born during the first and second halves of the same calving season and the effects of birth period on the development of males until slaughter, as yearlings, and of females until calving, after having mated at 13-15 months of age. Early-born females were heavier than those born late at weaning $(119.3 \mathrm{vs} 109.9 \mathrm{~kg} ; \mathrm{P}<0.05)$, at the start of the breeding season $(275.0 \mathrm{vs} 263.0 \mathrm{~kg} ; \mathrm{P}<0.05)$, and at the end of the breeding season $(300.0$ vs $289.5 \mathrm{~kg} ; \mathrm{P}<0.05)$, in addition to being more fertile $(70$ vs $50 \%$ pregnancy rate). There was no difference $(\mathrm{P}>0.05)$ in the development of males born early in relation to those born late, except for weaning weight, which was higher in the former. Steers born early were ready for slaughter at a younger age (459.6 vs 490.1 days; $\mathrm{P}<0.05)$, and both groups (early- and late-born) had a body condition classified as fat (4.21 points). In intensive production systems, both male and female calves perform better if they are born during the first half of the calving season.
\end{abstract}

Keywords: body condition, development, reproduction, finishing males

\section{RESUMO}

O objetivo deste estudo foi avaliar, por dois anos, o desempenho de 124 bezerras e 105 bezerros Braford nascidos durante a primeira e segunda metades da mesma estação, bem como os efeitos do período de nascimento no desenvolvimento dos machos até o abate e das fêmeas até o primeiro parto, após serem acasalados entre 13/15 meses de idade. As fêmeas nascidas precocemente foram mais pesadas do que as nascidas tardiamente ao desmame quando bezerras (119,3 vs. 109,9kg; P<0,05), no início da estação reprodutiva (275,0 vs. 263,0kg; $P<0,05)$ e no final da estação reprodutiva (300,0 vs. $289,5 \mathrm{~kg} ; P<0,05)$, além de terem maior fertilidade (taxa de prenhez 70 vs. 50\%). Não houve diferença $(P>0,05)$ no desenvolvimento de bezerros nascidos precocemente em relação aos nascidos mais tardiamente, exceto no peso ao desmame, com superioridade dos primeiros. Os novilhos nascidos mais cedo ficaram prontos para o abate à idade mais jovem (459,6 vs. 490,1 dias; $P<0,05)$, e ambos os grupos (nascidos precoce e tardiamente) tinham uma condição corporal classificada como gordura (4,21 pontos). Em sistemas de produção intensiva, os bezerros machos e fêmeas nascidos precocemente, na primeira metade da estação de parição, possuem melhor desempenho.

Palavras-chave: condição corporal, desenvolvimento, reprodução, terminação de machos

Recebido em 15 de janeiro de 2020

Aceito em 26 de maio de 2020

E-mail:rzvaz@terra.com.br 


\section{INTRODUCTION}

The processes involved in the intensification of beef cattle systems include reducing the number of growing or inefficient animals in the herd (Souza Silva et al., 2014). Reducing the age at first mating of replacement heifers and the slaughter age, in the case of steers, can increase the herds' offtake rate. To this end, planning the activity with specific targets and preventing possible problems are measures that help producers make decisions aimed at maximizing results (Rosado Jr and Lobato, 2011).

The average offtake rate of Brazilian beef cattle herds is around 23\% (Anuario..., 2018), and this percentage can be further increased by reducing mortality rates, the slaughter age of steers and the age at first mating of heifers, as well as increasing the pregnancy rate of breeding herds. The growing interest in the intensification of production systems has increased the selection of animals with potential for earlier development and manifestation of puberty, in the case of heifers (Restle et al., 1999), and earlier weight gain and fatness, in steers (Gottschall et al., 2007).

Several factors influence the earliness of maturity of animals in production systems, especially when these systems have fixed and predetermined mating periods. The feeding level is an essential aspect in obtaining the weights necessary for the first mating of heifers and for the slaughter of steers at predefined ages (Larson et al. 2011). In this context, the "two-year production system" (first mating of heifers and slaughter of steers at two years of age) is an already well-established concept.

A major challenge faced by producers is intensification aimed at reducing the age at first mating to $13-15$ months and the slaughter age to 18 months. Therefore, environmental conditions should be improved so that the genetic potential of animals can be expressed, and the necessary developments can be achieved. In intensive production systems, the adoption of management techniques and the earlier birth of calves positively influence productivity indices, yielding better economic results. The objective of this study was to analyze, for two consecutive years, the performance of steers and of heifers born in two sub-periods of the breeding season.
Males were evaluated until slaughter, as yearlings, while females were evaluated until the first calving (mating at 13-15 months of age).

\section{MATERIAL AND METHODS}

The experiment was carried out at Itú Farm, located in Itaqui - RS, Brazil (29 $12^{\circ}$ ' S latitude and $55^{\circ} 36^{\prime} \mathrm{W}$ longitude). The soil of the region is classified as a Dystrophic Red Latosol (Santos et al., 1999) and the climate is subtropical, according to the Köppen classification (Moreno, 1961). All procedures were approved by the Institutional Committee on Animal Use (CEEA $n^{\circ}$. 8250-2015).

The study involved 124 female and 105 male Braford calves. One hundred and eighteen cows were used, primiparous and secondiparous, respectively, at three and four years of age that repeated a pregnancy in the second year. Six bulls were used, being the same in the mating in the two years. Treatments were determined based on the birth date of the calves, which were divided into two groups within the calving season: Early (September 15 to October 20) and Late (October 21 to November 30). Calves were managed until weaning as a single group, with their dams, on a natural pasture at a stocking rate of $320 \mathrm{~kg}$ of live weight per hectare. The botanical composition of the natural pastures in the region is diversified, with the presence of grasses and plants of the family Compositae. The predominating species are Paspalum notatum at the highest portions and Fissifolius Axonopus in the wetter parts. Andropogon lateralis also occurs in the upper portion, and legumes of the genus Desmodium are present.

After weaning, which took place on average at 148 days post-calving, the calves were moved to a corral where they stayed 10 days. Afterwards, they were kept on a pearl millet (Pennisetum americanum) pasture until April. From May to November, they were kept on winter/spring cycle pastures of oat (Avena strigosa Schreb) and ryegrass (Lolium multiflorum Lam). From the first 10 days in the corral to the start of the winter-pasture grazing, all animals in the postweaning period received concentrate supplementation with $18 \%$ crude protein and $75 \%$ total digestible nutrients in an amount equivalent to $1 \%$ of their live weight. 
In the winter/spring grazing period, the animals were separated by sex and female calves and male calves grazed at the stocking rates of $1320 \mathrm{~kg}$ for heifers and $1160 \mathrm{~kg}$ for steers per hectare, respectively. After the winter/spring grazing period, steers were managed on cultivated pearl millet pastures from November to March, at an average stocking rate of $660 \mathrm{~kg} / \mathrm{ha}$. After the grazing period on the oat and ryegrass pastures, the heifers were moved to the natural pastures at a stocking rate of $280 \mathrm{~kg} / \mathrm{ha}$ and exposed to natural service for a period of 72 days. Bulls that tested positive in a libido and mounting ability test and an andrological examination were used at a bull/heifer ratio of $1: 25$. Pregnancy diagnoses were obtained by ultrasonography 30 days after the end of the breeding season.

All animals were weighed at birth, at weaning, and at the beginning and end of each grazing cycle, the weights being adjusted for the dates of the respective evaluation, using the weight previously adjusted as the initial weight of the phase. During the cycles on the different pastures, the animals were weighed every 28 days to control the stocking rate. Daily weight gain was determined as the difference in adjusted weight between the weighing sessions divided by the number of days between them. During weighing, the animals had their body condition score assessed (Rasby et al., 2014) by assigning values of 1 to 5 , where $1=$ too thin and $5=$ too fat.

Because no interaction was detected $(\mathrm{P}>0.05)$ between calving seasons within the birth season or calf sex for any of the studied variables, the data were analyzed separately for each sex by analysis of variance and means were compared by the $t$ test, using the mathematical model below:

$$
Y_{i j k}=\mu+P_{i}+E_{j}+\left(P^{*} E\right)_{i j}+A_{k}+\Sigma_{i j k},
$$

where: $\mathrm{Y}_{\mathrm{ijk}}=$ dependent variables; $\mu=$ overall mean considering all observations; $\mathrm{P}_{\mathrm{i}}=$ effect of age $i$ of observation of measurements, from birth to the first calving of heifers and slaughter of steers; $E_{i}=$ effect of calving period $j$ within the birth season $(j=1$ for the first half and $j=2$ for the second half); $\mathrm{P}^{*} \mathrm{E}_{\mathrm{ij}}=$ effect of the interaction between observation period $\mathrm{i}$ and calving period within birth season $\mathrm{j} ; \mathrm{A}_{\mathrm{k}}=$ effect of the year-k and cow-age set as a co-variable; and $\Sigma_{\mathrm{ijk}}=$ residual error.
Initially, one analysis was performed per year of evaluation, which revealed that there was no difference $(\mathrm{P}>0.05)$ between groups within the sexes in the different years. For this reason, the effect of year was removed from the model, as it is confused with cow age, the latter of which remained as a co-variable for the adjustment of the means. Analyses were undertaken using the GLM procedure, adopting 5\% as the maximum significance level. Means were compared by the " $t$ " test. The percentage of pregnancy variable was analyzed by the chi-squared test at the $5 \%$ significance level.

\section{RESULTS}

Female calves weight at birth was not influenced $(\mathrm{P}>0.05)$ by calving season, averaging $27.7 \mathrm{~kg}$ for female calves born in the first half (herein termed 'early-born') and $28.2 \mathrm{~kg}$ for those born in the second half ('late-born') of the calving season (Tab. 1).

However, during the suckling period, early-born female calves had a higher adjusted average daily weight gain $(0.619$ vs $0.552 \mathrm{~kg} ; \mathrm{P}<0.05)$ and were heavier (adjusted weight) at weaning at 148 days of age $(119.3$ vs $109.9 \mathrm{~kg} ; \mathrm{P}<0.05)$. After weaning, in the different evaluated stages, the average daily weight gain did not differ $(\mathrm{P}>0.05)$ between the two groups, but the early-born female calves maintained their higher values in the subsequent stages until the end of the first mating at $13-15$ months of age $(300.0 \mathrm{vs} 289.5 \mathrm{~kg}$; $\mathrm{P}<0.05)$.. The weight of early- and late-born female calves at the start of the reproductive period was equivalent to 61.1 and $58.4 \%$ of the adult weight of cows in the herd, respectively. The pregnancy rate in early-born heifers was higher by 20.14 percentage units compared with those born later in the calving season, which represents a $40.28 \%$ greater efficiency of the former.

Male calves developed similarly to female calves until weaning, with those born in the first half of the calving season gaining more weight until weaning than late born. Early-born male calves even those lighter at birth were heavier at weaning due to their greater weight gain (Tab. 2). Late-born male calves, in turn, did not differ in performance post-weaning and during the finishing stage, but remained in the system for a longer time (30.5 days) than early-born. 
Table 1. Means and standard error of the mean for development (adjusted weights) and reproductive traits of female calves born in two periods of the calving season

\begin{tabular}{lcc} 
& \multicolumn{2}{c}{ Calving season } \\
\hline Weight, $\mathrm{kg}$ & Early & Late \\
\cline { 2 - 3 } At birth & $27.7 \pm 0.2^{\mathrm{a}}$ & $28.2 \pm 0.2^{\mathrm{a}}$ \\
At weaning & $119.3 \pm 2.1^{\mathrm{a}}$ & $109.9 \pm 2.4^{\mathrm{b}}$ \\
Early winter & $164.4 \pm 2.5^{\mathrm{a}}$ & $154.1 \pm 2.9^{\mathrm{b}}$ \\
Early breeding season & $275.0 \pm 3.4^{\mathrm{a}}$ & $263.0 \pm 3.8^{\mathrm{b}}$ \\
Late breeding season & $300.0 \pm 3.6^{\mathrm{a}}$ & $289.5 \pm 3.9^{\mathrm{b}}$ \\
At calving when primiparous & $356.7 \pm 5.4^{\mathrm{a}}$ & $353.6 \pm 7.5^{\mathrm{a}}$ \\
At weaning when primiparous & $363.6 \pm 6.8^{\mathrm{a}}$ & $361.2 \pm 9.2^{\mathrm{a}}$ \\
Of calf at birth & $30.6 \pm 0.58^{\mathrm{a}}$ & $31.4 \pm 0.82^{\mathrm{a}}$ \\
Daily weight change,kg & & \\
From birth to weaning & $0.619 \pm 0.014^{\mathrm{a}}$ & $0.552 \pm 0.016^{\mathrm{b}}$ \\
From weaning to breeding season & $0.623 \pm 0.009^{\mathrm{a}}$ & $0.612 \pm 0.010^{\mathrm{a}}$ \\
During the breeding season & $0.375 \pm 0.009^{\mathrm{a}}$ & $0.385 \pm 0.018^{\mathrm{a}}$ \\
Body condition, points & & \\
Early winter & $2.74 \pm 0.02^{\mathrm{a}}$ & $2.75 \pm 0.02^{\mathrm{a}}$ \\
Early breeding season & $3.75 \pm 0.03^{\mathrm{a}}$ & $3.70 \pm 0.04^{\mathrm{a}}$ \\
Late breeding season & $4.32 \pm 0.03^{\mathrm{a}}$ & $4.28 \pm 0.04^{\mathrm{a}}$ \\
Reproductive performance, $\%$ & & \\
Pregnancy rate at 13/15 months of age & $70.14^{\mathrm{A}}$ & $50.00^{\mathrm{B}}$ \\
\hline A, B differ by the Chi-squared test $(\mathrm{P}<0.05)$; $^{\mathrm{a}, \mathrm{b}}$ in the same row differ $(\mathrm{P}<0.05)$ by the F test.
\end{tabular}

Table 2. Means and standard error of the mean for development (adjusted weights) traits of male calves born in two periods of the calving season

\begin{tabular}{|c|c|c|}
\hline \multirow{2}{*}{ Variable } & \multicolumn{2}{|c|}{ Calving season } \\
\hline & Early & Late \\
\hline \multicolumn{3}{|l|}{ Weight, kg } \\
\hline At birth & $31.0 \pm 0.21^{\mathrm{b}}$ & $31.8 \pm 0.21^{\mathrm{a}}$ \\
\hline At weaning & $124.4 \pm 2.42^{\mathrm{a}}$ & $116.8 \pm 2.49^{\mathrm{b}}$ \\
\hline Early winter* & $167.9 \pm 2.92^{\mathrm{a}}$ & $161.0 \pm 3.10^{\mathrm{a}}$ \\
\hline End of winter* & $297.5 \pm 3.99^{\mathrm{a}}$ & $290.2 \pm 4.02^{\mathrm{a}}$ \\
\hline At slaughter & $349.3 \pm 3.81^{\mathrm{a}}$ & $340.4 \pm 4.36^{\mathrm{a}}$ \\
\hline \multicolumn{3}{|l|}{ Age, days } \\
\hline At slaughter & $459.6 \pm 10.1^{\mathrm{a}}$ & $490.1 \pm 11.0^{\mathrm{b}}$ \\
\hline \multicolumn{3}{|l|}{ Daily weight change,kg } \\
\hline From birth to weaning & $0.626 \pm 0.015^{\mathrm{a}}$ & $0.580 \pm 0.016^{\mathrm{b}}$ \\
\hline Winter & $0.715 \pm 0.024^{\mathrm{a}}$ & $0.718 \pm 0.025^{\mathrm{a}}$ \\
\hline Summer ${ }^{\#}$ & $0.740 \pm 0.028^{\mathrm{a}}$ & $0.721 \pm 0.026^{\mathrm{a}}$ \\
\hline \multicolumn{3}{|l|}{ Body condition, points } \\
\hline Early winter & $2.86 \pm 0.02^{\mathrm{a}}$ & $2.86 \pm 0.02^{\mathrm{a}}$ \\
\hline End of winter & $3.83 \pm 0.03^{\mathrm{a}}$ & $3.80 \pm 0.03^{\mathrm{a}}$ \\
\hline End of summer (slaughter) & $4.21 \pm 0.02^{\mathrm{a}}$ & $4.21 \pm 0.03^{\mathrm{a}}$ \\
\hline
\end{tabular}

a,b Means in the same row differ $(\mathrm{P}<0.05)$ by the $\mathrm{F}$ test.

* Period of winter and spring, animals kept on cultivated oat and ryegrass pasture.

\# Period of summer, animals kept on cultivated pearl millet pasture.

Body condition scores did not differ $(\mathrm{P}>0.05)$ on any of the dates evaluated until slaughter (male calves) or until the end of the breeding season (female calves). Mean values for body condition score at those times were 4.21 and 4.30, respectively, which categorizes the animals as fat (Rasby et al., 2014), thus meeting the market demands in terms of fatness (male calves) and reproductive success (female calves). 


\section{DISCUSSION}

The higher weaning weight of early-born female calves is a result of the higher availability and better quality of forage during the lactation period (Bocchi et al., 2004). This fact was mostly present at the time of peak lactation, when female calves had a greater weight gain, besides their longer suckling period under nutritional conditions favorable to their mothers for milk production than those born in the second half of the calving season (Carneiro et al., 2012), since both groups were weaned on the same date. Higher weights and older ages at weaning provide higher pregnancy rates in heifers exposed to bulls at 13-15 months of age (Rocha and Lobato, 2002; Vaz and Lobato, 2010).

The weight at first mating is an indicator of pregnancy in the first reproductive period (Nutrient..., 2016). Female calves born later in the calving season may not have the desired weight at the beginning of the first breeding season if they are mated at 13-15 months of age. This can be explained by their lower age and reduced suckling period, than early-born heifers. The more intensive a system is, with pregnancy occurring at 13-15 months of age, the more important the date of birth and the duration of the suckling period will be (Vaz et al., 2012; Funston and Larson, 2011), with better responses in reproductive performance (Vaz and Lobato, 2010; Larson et al., 2011).

Despite there being no difference in the average daily weight gains adjusted for the animal's age post-weaning and during the breeding season, the older age and higher weight at weaning were determinants of the better reproductive response. In more-intensive systems, pregnancy is related to the age, development, and physiological maturity of heifers, in addition to interactions among these factors. Female calves late-born (average weight to $263 \mathrm{~kg}$ at the beginning of the breeding season) had a pregnancy rate of $50 \%$, which are the heaviest in the group, since pregnancy rates in this animal category increase linearly with body weight (Rosa et al., 2012). Stratifying a herd of heifers in weight ranges Vaz and Lobato (2010) observed that heavier weights meant higher pregnancy rates.

Age is a crucial factor to the reproductive success of heifers in intensive systems. Vaz and
Lobato (2010) when evaluating for two consecutive years, heifers born from the same herd of cows from birth to the first mating at 1315 months of age, with consecutive pregnancies and mated to the same bulls, verified that heifers born in the second year of the study were 25 days younger at the beginning of their mating season, with a lower pregnancy rate of $19.3 \%$ compared to the first year of evaluation (57.55 vs $68.65 \%$, respectively). These facts prove that puberty and subsequent pregnancy are associated with body weight and age (days) of heifers and that these factors are integrated (Restle et al., 1999). Besides that, early-born female calves in calving season conceive at the beginning of the breeding season and are the ones that present the highest pregnancy rate as primiparous cows (Vaz et al., 2010), have higher productivity and heavier calves at weaning (Lobato and Magalhães, 2001). A higher calving concentration at the beginning of the calving season allows a greater calving interval at the end of the second breeding season (Osoro 1986).

The higher weight of early-born female calves did not influence their subsequent weights at calving and weaning nor the weight of their calves, as primiparous cows, diluting the greatest development until the first mating during the first gestation period, especially when exposed to non-ideal nutritional conditions, due to increased demands for lactation which are increasing (Castilho et al., 2018; Silva et al., 2018).

The higher birth weights of late-born calves are a result of the association between better forage allowance and quality (Viu et al., 2006) and to greater fetal growth which is higher in the last third of pregnancy (Carneiro et al., 2012). Cows receiving better nutritional conditions in the last third of pregnancy more adequately supply their needs and that of fetuses, which reflexes in heavier birth weight of their calves (Viu et al., 2006). This also directly contributes to the energy reserves of cows, leading to higher body condition scores, higher milk production, and better development of their calves (Carneiro et al., 2012).

The greater development of early-born male calves until weaning is the result of the better nutritional level of the cows, which allows them to produce more milk, leading to higher weights at weaning (Brauner et al., 2011). After the 
lactation peak, older calves become ruminants and can graze at qualitative levels adequate to their development (Viu et al., 2006). Lower development pre-weaning leads to lower revenues, compromising the profitability of the system. In productive systems to increase the revenues in kilograms of calfs born late, the mother cows must have better nutritional level to produce more milk (Oaigen et al., 2009).

The heavier weight at weaning of early-born male calves compared with late-born male calves is significantly reduced over time. This similarity in weight shown by the male calves at slaughter, unlike the females at 13-15 months of age, is the result of the better nutritional level provided post-weaning to the male calves, in the productive systems due to the efficiency of this category (Gottschall et al., 2007; Pereira et al., 2016).

The period an animal is kept in the production system is a key factor for efficiency (Nichelle $e t$ al., 2015). The pre-weaning development of male calves in intensive systems, has an impact on the efficiency of transformation of feed into weight gain (Gottschall et al., 2007; Vaz et al., 2012). Keeping less-efficient animals in the system for longer period results in higher costs. Lower body weights of males born at the beginning of grazing forage for high performance delay the achievement of the target weight and degree of finishing. These factors may determine an extended stay of the animals in the system or even the use of feedlots for finishing (Mello et al., 2009), which affects the production efficiency of the system (Nichelle et al., 2015).

Production systems do not benefit from steers spending an extended time in the growing and finishing stage, since their requirements for maintenance will be increased (Mello et al., 2009). Lower development in certain growth stages of steers can be recovered later. The younger the recovery of the animals, the more economical it will be for the productive systems, given the loss of efficiency of transformation of the feed as the finishing period advances and the animal gains weight (Mello et al., 2009).

\section{CONCLUSIONS}

Regardless of sex, the calf birth period influences the performance rates of animals in production systems where fixed mating times are adopted. Male calves born in the second half of the calving season are heavier at birth. Male calves and female calves born early in the calving season are heavier at weaning. Female calves born early have better reproductive responses with mating at 13-15 months of age.

\section{REFERENCES}

ANUÁRIO da pecuária brasileira. São Paulo: FNP, 2018. 280p.

BOCCHI, A.L.; TEIXEIRA, R.A.; ALBURQUERQUE, L.C. Idade da vaca e mês de nascimento sobre o peso ao desmame de bezerros nelore nas diferentes regiões brasileiras. Acta Sci. Anim. Sci., v.26, p.475-482, 2004.

BRAUNER, C.C.; PIMENTEL, M.A.; MENEZES, L.M. et al. Effect of short period feed supplementation during early lactation on performance of cows and calves raised in extensive system. Rev. Bras. Zootec., v.40, p.1381-1387, 2011.

CARNEIRO, L.C.; SILVA, J.C.C.; MENDES, G.P. et al. Efeito do mês de parição na taxa de gestação subsequente e no peso ao desmame dos bezerros de vacas Nelore. Acta Sci. Vet., v.40, p.1030-1034, 2012.

CASTILHO, E.M.; VAZ, R.Z.; FERNANDES, T.A. et al. Precocidade de parto na estação de parição sobre a eficiência produtiva de vacas primíparas aos 24 meses de idade. Cienc. Anim. Bras., v.19, p.e46667, 2018.

FUNSTON, R.N.; LARSON, D.M. Heifer development systems: dry-lot feeding compared with grazing dormant winter forage. J. Anim. Sci., v.89, p.1595-1602, 2011.

GOTTSCHALL, C.S.; CANELLAS, L.C.; FERREIRA, E.T. et al. Avaliação de três diferentes categorias de bovinos de corte terminados em regime de confinamento. Rev. Bras. Saúde Prod. Anim., v.8, p.61-70, 2007.

LARSON, D.M.; CUPP, A.S.; FUNSTON, R.N. Heifer development systems: a comparison of grazing winter range or corn residue. J. Anim. Sci., v.89, p.2365-2372, 2011. 
LOBATO, J.F.P.; MAGALHÃES, F.R. Comportamento reprodutivo de vacas primíparas aos 24 e 36 meses de idade. Arq. Fac. Vet., v.29, p.139-146, 2001.

MELLO, R.; RESENDE, F.D.; QUEIROZ, A. C. et al. Bio-economicity of the finishing phase on feedlot of crossbred young bulls slaughtered at different body weights. Rev. Bras. Zootec., v.38, p.109-121, 2009.

MORENO, J.A. Clima do Rio Grande do Sul. Porto Alegre: Secretaria da Agricultura. 1961. $41 \mathrm{p}$.

NICHELLE, E.M.; MORAES, E.H.B.K.; ARAÚJO, C.V. et al. Eficiência bioeconômica de bovinos de corte em confinamento. Rev. Bras. Saúde Prod. Anim., v.16, p.699-711, 2015.

NUTRIENT requirements of beef cattle. 8.ed. Washington: National Academy Press, 2016. 494p.

OAIGEN, R.P.; BARCELLOS, J.O.J.; CHRISTOFARI, L.F. et al. Análise da sensibilidade da metodologia dos centros de custos mediante a introdução de tecnologias em um sistema de produção de cria. Rev. Bras. Zootec., v.38, p.1155-1162, 2009.

OSORO, K.O. Effecto de las principales variables de manejo sobre los parametros reproductivos en las vacas de cria. Prod. Sanid. Anim., v.1, p.87-111, 1986

PEREIRA, L.C.; MATEUS, R.G.; CARVALHO, C.M.E. et al. Avaliação da viabilidade para produção de bezerro de corte a partir dos centros de custo. Rev. Ens. Pesqui. Adm. Eng., v.1, p.188209, 2016.

RASBY, R.J.; STALKER, A.; FUNSTON, R.N. EC07-281 body condition scoring beef cows: a tool for managing the nutrition program for beef herds. Lincon: University of Nebraska. 2014. $14 \mathrm{p}$.

RESTLE, J.; POLLI, V.A.; SENNA, D.B. Efeito de grupo genético e heterose sobre a idade e peso a puberdade e sobre o desempenho reprodutivo de novilhas de corte. Pesqui. Agropecu. Bras., v.34, p.701-707, 1999.

ROCHA, M.G.; LOBATO, J.F.P. Sistema de alimentação pós-desmama de bezerras de corte para acasalamento aos 14/15 meses de idade. Rev. Bras. Zootec., v.31, p.1814-1822, 2002.
ROSA, A.A.G.; VAZ, R.Z.; LOBATO, J.F.P. Natural and improved pastures on the growth and reproductive performance of Hereford heifers. Rev. Bras. Zootec., v.41, p.203-211, 2012.

ROSADO JUNIOR, A.G.; LOBATO, J.F.P. Implementation of a performance indicators system in a beef cattle company. Rev. Bras. Zootec., v.39, p.1372-1380, 2011.

SANTOS, H.G.; JACOMINE, P.K.T.; ANJOS, L.H.C. et al. Sistema brasileiro de classificação de solos. Brasília: Embrapa Cerrados / Rio de Janeiro: Centro Nacional de Pesquisa de Solos, 1999. 412p.

SILVA, M.D.; LOBATO, J.F.P.; VAZ, R.Z. et al. Development and reproductive performance of Hereford heifers of different frame sizes up to mating at 14-15 months of age. Rev. Bras. Zootec., v.47, e20170031, 2018.

SOUZA SILVA, G.; COSTA, E.; BERNARDO, F.A. et al. Panorama da Bovinocultura no Rio Grande do Sul. Acta Sci. Vet., v.42, p.1215-1221, 2014

VAZ, R.Z.; LOBATO, J.F.P. Efeito da idade de desmame no desempenho reprodutivo de novilhas de corte expostas à reprodução aos 13/15 meses de idade. Rev. Bras. Zootec., v.39, p.142-150, 2010.

VAZ, R.Z.; LOBATO, J.F.P.; RESTLE, J. Influence of weaning age on the reproductive efficiency of primiparous cows. Rev. Bras. Zootec., v.39, p.299-307, 2010.

VAZ, R.Z.; RESTLE, J.; PACHECO, P.S. et al. Ganho pré e pós-desmame no desempenho reprodutivo de novilhas de corte aos quatorze meses de idade. Cienc. Anim. Bras., v.13, p.272$281,2012$.

VIU, M.A.O.; LOPES, D.T.; GAMBARINI, M.L. et al. Efeito da época do parto, idade materna e sexo sobre o desempenho pré-desmama de bezerros Nelore (Bos taurus indicus), criados extensivamente no centro-oeste do Brasil. Arch. Vet. Sci., v.11, p.75-79, 2006. 